\title{
FACTORS THAT REALLY BACK CREATES OF FAIR WOMEN'S PARTIES CASE STUDY IN DISTRICT SAMBAS
}

\author{
Mujahidin Bin Ali Said \\ Faculty Tarbiyah, \\ Sultan Muhammad Syafiuddin Sambas Institute of Islamic Religion (IAIS), Indonesia \\ (Email: bangdemujahidin@gmail.com)
}

Accepted date: 13-03-2018

Published date: 11-07-2019

To cite this document: Said, M. A. (2019). Factors that Really Back Creates of Fair Women's Parties Case Study in District Sambas. International Journal of Law, Government, and Communication, 4(15), 274-284.

DOI: $10.35631 /$ ijlgc. 4150026

\begin{abstract}
This article talks about the factors which background overshadow divorce to sue from woman party, as it's his weak indication is the development of family resilience, because husband still pretends it's 'superior' and incoming wife in faction 'interior' cultural effect of patriarchy which symptom still in Subdistrict Sambas. Besides culture patriarchy, other dissimilar factors as height impeller mount the divorce of because of often the happening of hardness in domestic conducted by husband to wife, 'insincerity' husband to wife in the form of insincerity with the woman of is other dissimilar, economic limitation of family, the increase of knowledge and wife education in the case of comprehending conjugal right, that wife also have the rights to raise the divorce is so-called divorced sue. Research invention found, height of divorce number in pure Subdistrict Sambas as indication from wife reaction, because feeling do not hold up again to behavior digress the husband till action divorce to sue raised by wife of through Office of Religion Business to be recommended to Religion Justice (RJ) as final decision taker is later then released a Divorce Deed of through whole procedure which has been specified. height of divorce Number in Subdistrict Sambas is in fact assessed unique enough, because this subdistrict known as region girding predicate as industrial area or metropolis, but social change of existing society exactly inversely proportional from regional condition in fact, by showing lifestyle "hedonis" as its strength indication is influence of effect of availability various existing facility, among other things in the form of domestic port as instrument go out entry of external society and place with which is very often misused in Subdistrict Sambas.
\end{abstract}

Keywords: Divorce, Woman, Sambas

\section{Introduction}

Factually lives of people who actually still in the traditional level has now been shifted to the urban community. This social change was also hit on aspects of conjugal life, then transformed into a hurdle in managing the household life. That is, the disorder originally came from the life of the younger generation who often adopt forms of free thinking (free thinkers) and is 
expanding to poison morals and doctrinal couples in the context of the relatively young age of marriage. Not to mention the proliferation of sex are increasingly implicated recently added more transparency broadcasts pornographic movies, tabloids, magazines and even the internet via facilities mobile phone.

Problems of married life is part of the process of life that is built on trust and mutual awareness. Despite these problems from the perspective of sociology can be considered as a form of denial of the two kinds of rules that govern life and the lives of interpersonal behavior, as Soekanto (2004: 22) asserted that the rules governing private life to distinguish between the rules of trust with the rules of decency. If the rules of the trust aim among humans embrace the life of faith, then the rules of human decency aim to have a clean conscience. Increased temperamental heart and feelings in response to the problems of families who often throws it, it can be judged as the most substantial factor as the cause of the failure of marriage, until the collapse of family building. This is the same meaning as a form of failure of an act if it does not reach the target, because the goal of marriage is the realization of soul muthmainnah means quiet and harmonious family formation, namely a peaceful household.

Biologically seen humans will seem contemptible if the marriage does not promote life common sense (Siddiq, 2004: 76) in the sense of always emotion and avoid responsibility. It is inspiring that the magnitude of the problems faced by families hinted crush assessed feels so heavy, allowing motivator creation of dysfunctional interaction within the family. Irrational attitudes continue to be stepped up as the last and the search for truth values themselves are subjective in nature-not logical. As affirmed Baruch A. Brody in the (1993: 100) a lot of major societal problems arise in relation to the demands of justice and injustice.

Compensation of that is divorce or divorce and can be interpreted as a form of separation from the husband and wife, or a decaying rope legal marriage with legal divorce also. According Personality 'divorce is something that is permissible according to religion, but risky form is based on the hadith of the Prophet Muhammad in Zulfah (2003: 142) as narrated by Abu Dawud, Ibn Majah and al-Hakim that case was lawful but most hated God, is divorce. The hadith gives the meaning that before the state was forced to completely let there be no divorce, and it can be seen that if someone is going to do a divorce in the Religious (PA) prior constantly reminded by the employee concerned. The purpose and the aim are for the married couple had been able to feel better or refer again to build family harmony as usual.

The rise of divorce cases in the District of Sambas resulted conceived expression is already growing in the area of research that there is a reluctance of certain parties to marry for fear of the consequences, namely the occurrence of family breakdown leads to divorce, and by AlFikrul Islami and Mujtama 'al-munashir, by real if the growing assumption actually opens the opportunity for every person committing fornication, adultery although this should not be seen as a direct result of the divorce, but it should also be seen as an opportunity to apologize and get forgiveness. As a result, the physical needs and instincts are basic human potential that encourage people to perform an act (Rahman, 2003: 78). That is, when a man wants to meet the physical needs and instincts, generally bound by certain ways, and certain perceptions.

Other factors that lead to divorce take place between them in respect of dominance to change and maintain the values that are considered more in line with the times today's contemporary and demanding personality has married a woman-although-in contrast to previous eras are always guard her honor. One example, as revealed Nawawi (1993: 92) that most women today have been exposed to diseases like showing excessive makeup to men. Even among very few 
have a sense of shame. If it runs like a make-up with immodest dress hips. Their new values in society are changing the family system, usually bringing a result of increased failure in carrying out the role). When one of the parties, both wife and husband receives new ways, while others have not been willing to accept, then it can happen disagreement about the role and behavior of the actual liability. This may result in a lot of people are failing to carry out its role, based on new or old benchmark.

As marriage, divorce is also a process that includes a lot of concerning things such as; emotional, economic, social and official recognition by society through law. By Goode in Karim (1999: 135) said that every society has a different definition of conflict between couples of the conflict as well as the way to resolve it. It is intended that the notion of divorce is a "failure" is biased, because the marriage based solely on romantic love. Whereas all the mating system, if examined in depth, consisting of at least two people who lived with which each have desires, needs and desires, as well as the background and the social value may be different from each other, in this case Firestone in Beilharz (2003: 15) resting his hopes on the potential of the discussion contained in the new reproductive technologies as a means of overcoming the tyranny of the biological, an optimism that by the next feminist rated mistaken. As a result, the system can create tensions and unhappiness that is felt by all members of the family. Because the event something happens to a marriage-for example; divorce-then there will be problems that must be faced by couples who divorce and children and the community in the area of divorce.

Contested divorce is intended as a form of divorce-based lawsuit filed by the wife, that marriage with her husband to be broken. That is, there are internal reaction of the wife-sued or filed for a divorce-husband to drop the divorce or visit the Office of Religious Courts (PA) Sambas Regency locals for consideration there is a conflict that requires the integrity of marriage is no longer tenable to return to the role of religion-through KUA -As educative, rescue, social supervision, foster brotherhood and transformative. This is as though Kahmad (2000: 130) that overcome the problems that arise in the community that cannot be solved empirically because of their limited ability and uncertainties. That is, it is not uncommon KUA forced to take lawful action but hated by Allah, the divorce as an alternative to a final resolution.

Discussion about divorce are at least two conditions must be fulfilled for the behavior that leads to social exchange, that: (1) The behavior-oriented goals can only be achieved through interaction with others; and (2) Conduct should be aiming to acquire a means for achieving goals (Gulardi, 1999: 175). That is, the decision to divorce is easier to achieve on a pair that does not involve an emotional bond-love-deep. Conversely, couples who used to be married for love, is more difficult to break free from the emotional ties that once existed. Back to the marriage relationship that is not accompanied by a sense of love, it will not satisfy the culprit for the expected rewards are not met. This is presumably in line with the thinking Sztompka (2004: 4) that the creation of a balance or shock, the consensus or dissension, harmony or discord, cooperation or conflict, from the nature of the interplay of the overall characteristics of complex social systems. That is, there has been a shift or social change, where women at location research prefer widow-divorced-rather than continue to struggle in the maelstrom of family conflicts are judged too wasted time and eat the liver, if the integrity of the household is maintained, a moment with the support of the social system that is now formed, having been conditioned so as a result of the desire for freedom pragmatism a dream.

Hope happy married life turns out is not always as expected, because the required readiness achieves both inner and outer, especially about your husband or wife's ability to overcome all 
the problems that plagued both internally and externally families. Is something that is common of all the problems that plagued it gave birth to the protracted conflict and sometimes ironically ended in divorce. Given that no one could have guessed when the coming event of divorce despite the problems triggered by something which was considered small, then enlarged until finally taking a toll, the harmonization of family life. That is, a divorce can affect anyone, regardless of social status, rank and position because divorce is the accumulated anger of the wife nor the husband is unbearable. The phenomenon of divorce, as happened in the entire life of families in Sambas, at least indicate that there has been a shift in values and norms that lead to social change, especially regarding the views and behavior of the factors of the background of divorce, especially divorce accountable conducted by the wife of the existence of marriage lived with her husband before.

Contested divorce taken the wife against the husband in the District of Sambas due to several factors, namely: (1) The release properties of the husband origin characterized by high levels of excessive egoism husband, so often put out profanity and mild hand against wives .; (2) The economic argument family, to lead to quarrels and physical violence against wives; (3) Problem of infidelity, since she considered that cheating husband made a big mistake and can no longer to be forgiven; (4) The husband is a migrant worker cause serious breakdowns in communication links, so that his wife no longer accept living, both physically and spiritually; (5) Physical violence committed husband to wife; and (6) Effect of changes in the environment lead to forms of modernity, because the wife feels his position has been aligned with the husband, even leading to the neglect of the functions of the wife in the household. The conflict in the family is more a form of combat between spouses, mainly due to the value factor, such as; money, attention, power and authority. Though both husband and wife should be able to wisely negotiate or hold a bidding process in achieving a common goal. When not, there is a match for each party, both husband and wife continue to survive on the attitude of each even attempt to build a sense of mutual cripple, which is the main trigger factor for divorce mainly done by the wife, given a general victims of the conflict in the internal wife's family is because often receive treatment that is not fair psychologically and physically. Ihromi (1999: 280) confirms that the latest efforts to resolve the divorce actually perform a search of consensus or suitability understood as a means of conflict management. Power or ability to influence the interaction and the result is that the main steering force in the family.

Various background factors accountable occurrence of divorce conducted by wives against their husbands in Sambas district, has a positive correlation as expressed by Surada Religion Sambas District Court judge that was published in Voice Editor in Chief, Friday (02/24/2016). Surada explained, the divorce rate in Sambas district and sub-district increased Sambas rated dominate. In comparison to the last three years seen in 2004 totaled. Every year, the divorce rate in Sambas district is increasing. Based on data from the Religious Courts (PA) Sambas, recorded in 2014, contested divorce cases that have been settled 627 cases. In 2015 increased to 739 cases and continues to rise as much as 805 cases in 2016 . Of the 805 cases, there are several cases of which are contested divorce cases are still in process.

The reason is dominant over the high divorce rate are on average as a result of living are not met so that the husband divorced the wife sue. It is considered rational because it has for many years not to make a living for her husband to go abroad as migrant workers and has been a general understanding that if three consecutive months his wife and children do not get a living, the wife may divorce her husband, the average rate of divorce high in the age range 20 to 30 years, and employment and encourage education. Reality contested divorce is generally carried out by the wife in the town of Sambas and coming from the surrounding villages, so that it can 
be judged that there has been a process of social change that swept society. Moreover, the District of Sambas is a tourist area and the port that is entering the modern era, plus rampant nightlife includes various types of availability nightclubs and cafes. Courage wives have contested divorce because her husband had neglected its obligations rated as the head of the household, so that the life of husband and wife continue to have disagreements.

Based on the background exposure, the authors are interested in doing research on the factors that background contested divorce from the woman in the District of Sambas, given the position of actual wives are not under the husband but have the same rights and obligations in building family resilience in achieving life.

\section{Methods}

This study uses qualitative descriptive study that illustrates and explains the various components of the social situation of an object and subject of research, namely the factors of the background-contested divorce from the woman in the District Sambas Sambas district. This study used a qualitative approach to present descriptive data in the form of written words and informants, namely; the wife who did divorce accountable to the husband observed through interviews and observations. The descriptive analysis will describe and connect between the results obtained from in-depth interviews with a record in the field as a result of observation. Between what is seen and what is heard, carefully parsed into words so as to connect the concept of a more meaningful in assessing research problems. According Nawawi (1991: 63), descriptive research as troubleshooting procedures, investigated by depicting or describing the state of the subject or object of study (a person, institution, community, etc.) at the present time based on facts that appear as they are.

Furthermore, make conclusions as a result of the analysis of problems early research. Such assumptions are expected to generate propositions about factors that background the contested divorce of the woman in the District Sambas Sambas district. Type this approach through an intensive approach, a comprehensive depth and detail as well as to explore in depth the research problem and still maintain the integrity of the research object (Sanafiah, 1995: 22). In order to understand the basic concepts about the world of empirical to be studied, the researchers observe and understand social phenomena obtained in the field with regard to the factors of the background for divorce to sue as a form of implementation internally of the wife-woman-with down directly spaciousness and engaging with the community, and supported some of the literature, researchers are directly or indirectly should be able to explore social realities observed. Then the researchers will develop an interim conclusion as materials in the next observation. Research in this case is a generalization of certain patterns in social groups, so it applies only on a limited studied community, namely the District community Sambas Sambas district.

\section{Processing institution Divorced Sues}

That process reinstitution contested divorce case starts from KUA in order to give advice to couples. However, if the couple cannot be reconciled then subsequently contested divorce cases transferred to the Religious Court. the process at the level of the Religious Court also indirectly addressed and soon divorced at that time even if it meets the requirements. But postponed until next week and maybe even up to a month, with the hope that that is going to divorce remember and regain consciousness about married life, having first given advice. Another thing that can be judged that the evidence of the seriousness of the Religious Court in deciding the particular divorce their wives to sue for divorce, based on information Surada Religion Sambas District Court judge that any incoming jolt-divorce is necessary that married couples can be reconciled. 
The process can last for six months, beginning to call 3 times to her husband and calling 2 times against the plaintiff-the wife to give advice, and during the trial nature closed in the sense that should not be known to the public as a form of respect because it involves things the family is an internal matter. However, if the defendant-the husband-not willing to meet the call or insists on divorce straighten it in the sense of no longer willing to accept other forms of advice given by the Religious Courts (PA) so that the final hearing in the form of a decision divorce. At the hearing the divorce decision has been declared open for general consumption. Against the advice given in the form of business the Religious Courts visible yet can produce that married couples can be reconciled. It is characterized by high rates of divorce by a court verdict local religious than the willingness of couples to re-organize the home life.

Legally the granting of the divorce certificate and divorce accountable-regulated in Article 84 paragraph (4) jo. Article 72 of Law No. 71989 commissioned and became authority of the Clerk to the courts that hear and decide the case. Nevertheless, the Clerk of the Court or Court officials designated an obligation for 30 days of sending a single strand of a copy of the decision of courts that have obtained permanent legal force without stamped to VAT whose territory includes the residence of the plaintiff and defendant-ex-husband / wife litigants-to register the verdict divorce in the Register Divorced. While that was sent by the Registrar for registration in the Register Divorce is the determination of the judge stating that the marriage broke up since the divorce is pronounced, as stated in Article 71 paragraph (1) of Article 72 Jis Jis Article 84 paragraph (1) of Law No. 7/1989 Jis Article 29 Regulation of the Minister of Religion No. 2/1990.

The duties and authority of the Religious Court as provided for in Article 49 of Law No. 7 of 1989 is to examine, decide and resolve cases-cases at the first level among people who are Muslims in the areas of: (1) Marriage; (2) Inheritance, wills and grants made under Islamic law; and (3) Endowment and alms. Furthermore, based on Law No. 3 of 2006, on the Revision of Law No. 7 of 1989 on the Religious Courts Religious Courts authority increases, which handles disputes about Shariah Economy, determining the origin of a child and establishment of adoption under the laws Islam. That is, in carrying out these tasks are certainly needed the work program set out in the action plan in accordance with their respective tasks and staff officers. To support the basic tasks needed to support the program as stated in the work program. In order to determine the success of the work program which has been set then drafted an annual report as the realization of the work program, its goal was twofold: to evaluate the implementation of the work program as well as the material wisdom work program that will come next will be obtained better results in addressing all problems obstacles faced and solutions found as well as businesses.

The Islamic Court Sambas working basis, are: (1) Basic Law 1945; (2) of Law No. 4 of 2004 on the basic provisions of judicial power; (3) of Act No. 5 of 2004 on the Supreme Court; (4) Act No. 1 of 1974 on marriage; (5) of Law No. 7 of 1989 on Religious Courts; (6) law No. 41 of 2004 on endowments (7) of Government Regulation No. 4 of 1958 on the establishment of the Religious Court / Supreme Shariah Sambas district; (8) of Government Regulation No. 9 of 1975 on the implementation of Law No. 1 of 1974; (9) of Presidential Decree No. 1 of 1991 on the compilation of Islamic law; (10) of Presidential Decree No. 14 of 2004 on the implementation of the transfer of the affairs of the organization, administration and finance at the General Courts, Administrative Courts and the Religious Courts to the Supreme Court; (11) the Supreme Court Decree No. KMA / 001 / SK / I / 1992 on the pattern of development and administrative control registrar Religious Court and the High Court of Religion; (12) the Supreme Court Decree No. KMA / 004 / SK / II / 1992 on the organization and functioning of 
the Court clerkships Religion and Religious High Court; (13) of Law No. 3 of 2006 on the revision of Law No. 7 of 1989 on Religious Courts; (14) KMA No. 80 of 2006 on judicial standards, guidelines and supervision of the Religious Courts; (15) KMA No. 96 of 2006 on the supervision and guidance; and (16) other legislation relating to the duties of the Religious Courts. While institutions are closely linked to the problem of divorce is the Religious Affairs Office who initiated couples with marital bond, to head of household harmony that became the desire of each pair that have been submitted by the counsel BP-4 in the Office of Religious Affairs as well as things that can undermine a household was delivered with the expectation that the couple will build a harmonious household can be realized.

Sambas Sub-district Office of Religious Affairs is responding to every couple who came for advice in solving problems of domestic disputes with the counsels submitted that the dispute can be resolved and can be reconciled. Had good intentions submitted to the pillars back spouses are not reached, the issue will be authorized to process the Religious Court as the previous sex planation.

\section{Factors the Background of High-Sues Divorced in District Sambas}

Basically, the relationship between husband and wife is a relationship based on the principle of a relationship in the sense of mutual understanding, mutual respect and mutual support. The relationship of husband and wife is not merely formalistic relationship but should be more than that. The hope is to create a sense of tranquility and peace for mutual understanding even aware of their rights and obligations, as something that must be known by the couple. Conversely, if the fabric of conjugal life less aware of the meaning of rights and responsibilities rated vulnerable to irregularities, injustice to cause conflict in married life, it can even lead to the creation of violence in the home or often abbreviated to domestic violence.

If explored in depth based on the findings indicate that the high divorce rate, especially divorce on the grounds of contested divorce at the wife in the form of Religious Court case references data (PA) Sambas 2016 as the highest ranking, include; divorce 17 cases and as many as 48 cases of contested divorce. The high level of initiative of the wife filed for divorce to sue is generally based on the grounds of infidelity with domestic violence. Infidelity is based on the basic word, namely; cheating by Indonesian General Dictionary implies fraudulent, dishonest, not forthright indicated even corrupt. Against this, in relation to the assessment in the constitution regarding the implementation of all legislation until the regulations on marriage, family life among its applications there is still a good infidelity activity carried out by the wife nor the husband. This implies that the affair happened obviously have violated the commitment and the sanctity of marriage as between a husband and wife have denied responsibility to the family. Even on infidelity husband do the appropriate context of this study suggests that there has been a relationship unfair played by husbands against wives with cheating, dishonest even indicated corrupt on family finances for activities revel in extremes with women other than his wife. This injustice is not impossible refract distress that the wife to decide to end a marriage with her husband.

Opportunities for the husband was having an affair of which are also inconsistencies in some of laws and regulations are considered unfair, as far as is known and is based on observations that can be done, ranging from the entry into force still Marriage Law No. 1 of 1974 assessed gender bias. Gender bias in this case meant when doing an assessment of the Marriage Law No. 1 of 1974 precisely in Article 3 which implies to allow polygamous husband to open up opportunities for women may not marry more than one person. On the possibility this may 
polygamous husband inspired to do marriage again, which usually begins with the activity of an affair with another woman, either secretly or hide openly. That is, if something goes wrong and another example of deposits required to marry women due to pregnancy and so on in a court warrant also allowed. Provided to obtain more wives than one condition must obtain permission from his previous wife. That is, polygamy is a concrete manifestation of male hegemony in the household and the wife consent does not negate the hegemonic nature of the system such marriages. Requirements this permission, as happened in the field are often overlooked or given by the wife in distressed situations.

In Article 31, the law also defines the family of the husband and the wife as homemaker. Role as head of the family is still considered to be the cause decision-making tends to be monopolized by the husband. Similarly, to other forms of savings and loan transactions legally as do financial loans with banks for example, it is known if borrowing made by parties who have been married then have to get the approval of her husband. The establishment of rules that often puts the husband as head of the family often creates some problems when a household headed by women (single headed household) that has been officially divorced. That is, many cases were found in the field, where the household like this difficulty in gaining access to banks and not to be involved in public decision-making, the consequences often occur habits patterned in District Sambas to soon again married after the divorce experienced by no longer set questions that the option to get her husband back if they have a wife or still single. In fact, there is a widespread assumption that was already done for the widows in the area if you get a husband who has married judged to have the independence and the value of life has had sufficient reliability than if the marriage with a virgin.

\section{Contextuality Justice Divorced-Sues Against Husband in District Sambas}

Instinctively every human behavior tends to lead to forms of independence and has a desire to get the recognition of other human beings in social contact, as well as for the wife in the family life with her husband and children, this trend occurs with age more productive life. Productivity someone can start since a person aged 15 years and over until you reach the age limit of 64 years.

Regarding the size of one's maturity sociologically strongly influenced the level of internalization in the family and its ability to socialize well with the environment. When both processes are family internalization and socialization with negative environment then it is possible to form a person's attitude and character become negative, such as; have a hard stance and tend to behave violently as a trigger of acts of violence, leading to oppression to others.

Based on various information either through the police, YLBH-PIK and Religious Courts (PA) Sambas District and KUA in district Pemangkat generally have alignment in assuming. That is, about 90 percent of family life has experienced domestic violence and is generally considered to occur in a non-physical, while physical violence is assessed half and that was not all that was reported to the authorities. What happens in the Pemangkat Subdistrict is a small part of domestic violence if viewed in the Indonesian context. The number of cases of domestic violence that lead to the divorce rate is considered increasing. Even over the past year, 22,000 cases of domestic violence have been reported throughout Indonesia. That means, increased 5fold over the previous year which only 4 thousand cases. Increasing cases of domestic violence according to the State Minister of Women's Empowerment Meutia Hatta Swasono does not mean cases of violence that occur in the community increases, it's just because there is a law of domestic violence, so people who experience it tend to be more intrigued to report cases experienced (Gemari, 2007: 42) including the courage of a wife to divorce a lawsuit. It's just 
as quoted from various observations of the competent parties that physical violence is more prevalent in married couples between the ages of 17 years to 30 years, while non-physically tend to not know the age limit in the sense can occur anytime and anywhere based on one's unsteady status.

In addition, today's educational factors are often used as a measure in assessing the quality of wives, because the higher the level of education that is assumed to have a significant effect on awareness and establishment of the wife in living his life, so it is not mistaken for education to continue to be the essential need for humans in the life the more dignified. However, in this study, it is not always the educational factor to guarantee a person apart from violent acts, but at least because of the insight that his wife has had in his education can immediately behave, even daring to sever his relationship with the husband through a divorce. This study is considered sufficient as evidence that domestic violence is also always experienced by informants whose education ranging from elementary school graduate, high school to hold a degree (S-1) with the source of the trigger glamorous modern life that led to promiscuity and infidelity, so the husband had started daring to do comparison- a comparison between a wife and a woman whose affairs usually give more physical life. The depth of religious understanding for wives also makes the basis of argument for unanimously determined divorce. Because a number of informants who have ended their family with their husbands and retained the self-respect generally admit that religious values are strongly believed to be the source of life and guidance to gain happiness in the world and in the hereafter. That is, all religions always teach their people about the values of goodness that must be developed based on His teachings and commands, and away from all sinful acts as a prohibition that should not be done. As Soekanto (2004: 22) asserted, that the rules governing private life are distinguished between the rules of trust and the rule of decency. If the principle of trust aims between humans to live a faithful life, then the principle of decency is intended for people to have a clean conscience.

It has become universal recognition that to a number of recognized religions in Indonesia it can be ascertained that all of its teachings do not justify a person or a particular party engaging in violence or oppression of another person or party, let alone a wife as part of the husband's life, sin is also believed to affect the relationship of friendship from the interaction process that he does together. That is, when two humans are different types of marriage ceremony then the indication that must be fostered is harmony and simplicity in living the household ark, so that one of them can build togetherness and cover each other's deficiencies. To the exploitation of domestic violence, it is clear that it is an act of sin because there are parties who feel oppressed and hurt even if done in a non-physical (mental). It's just the reality in this study, not all married couples are able to understand and practice all the teachings of religion that is adhered to so well, so that domestic violence as the beginning trigger the occurrence of divorce always happen, even difficult to be separated as romantic household.

Another argument is that a wife is willing to make a divorce proceeding to the Religious Court (PA) for work reasons. Jobs owned by the wife, based on a number of acknowledgments of informants who have experienced the divorce process until the official divorce with the husband is a concrete indication in listening to the productivity of a wife. If referring to the statement is considered not all true, given the nature of the job as life guidance is binding, especially economically in order to meet all their needs. That is, the type of work that someone is involved in the attitude and personality, although this is not entirely true. The proof, one of the informants who work as community service, namely; Civil servants are often perceived to put forward forms of violence in solving all the problems faced in the household. Consequently, 
as Gulardi pointed out in Ihromi (1999: 168) that the new values in society that alter the family system will usually lead to increased failure to perform the role.

The reality of the condition, when meeting with other informants' initials $\mathrm{Si}$ (38 Th) which in his statement explicitly said that now he is experiencing the process of divorce to terminate the life of married life with her husband. The filing of the divorce was forced to do because it felt the atmosphere of domestic life with her husband often shrouded in an atmosphere of contention and often involving the families of each party. Even by his neighbor Iis (45 Th) sometimes feels uncomfortable, if his neighbor is fighting who seems to not know the time even at night when people use it for a night sleep. Basic mismatch so that Si divorce due to husband's betrayal of adultery accompanied by the occurrence of forms of violence in the family, in the form of action based on sex, resulting in misery and suffering physically also psychological wife. It may be perceived as a threat in the form of a particular form of action, coercion or arbitrary deprivation of liberty occurring in the personal environment (family) perpetrated by the husband or against some family members (children) to impose unilateral dependence and domination on other family members. In addition to this proves that social life in Sambas. Subdistrict has undergone a change, especially regarding the behavior of the young generation and young couples from the previous norm leading to deviation of norms as a pioneer. As Robert Biersted observed in Stompka (2004: 294) that deviation from the old structure is almost certainly part of the process of creating a new structure. This is considered in line with the work of Ferdinant Tonnies in Sztompka (2004: 27) on social change beginning with his doubt about the nature of progress leading to the negative impact of social change that the kindness of the former traditional society (gemeinschaft) has been replaced by urban community type (gesellschaft), industrial and modern. Ferdinant Tonnies' thoughts about traditional community communities (gemeinschaft) and the modern community (gesellschafts). Gemainschaft marked a personal relationship or familial relationship; while gesellschafts is characterized by an impersonal or business relationship. Other factors also exist that come from the economy of the parents or relatives, there is also coming from the awakening of romance or jealousy. Disorders that come from the cause of romance and jealousy include the disturbance that comes from yourself. Against such disturbances, the disruption of economics is ranked first. To the case of romance or jealousy usually economic factors there is no problem, but in general in every married life a bit much there must be interference.

\section{Conclusions}

The rise of divorce cases in Sambas sub-district due to family economic factors such as lack of basic needs fulfillment, husband's betrayal in the form of an affair with other women, the influence of environment and society conditions that have adopted the influence of modernization towards the glamor of hedonistic behavior, and the occurrence of domestic violence. The filing of divorce against husband by a number of wives in districts Sambas as a show of reaction directed to the Religious Court for the attitude and behavior of husbands who considered unrealistic, just looking for freedom and pleasure alone without thinking of his responsibility to the family. The process of divorce in an attempt to get a divorce certificate was not as easy as turning the palm of the hand, because in addition loaded with procedures that must be passed. That is, a new divorce case can be decided by the judge as a forced act, after no other solution for both husband and wife to peace or reconciliation. The efforts that need to be done include preventive action (Increasing the welfare of the family so that the fulfillment of needs, minimum basic needs of the family), (2) Establish an educative psychology guidance clinic, to consultation so that all family members can solve problems that are difficult to solve, (3) Provide a training ground to channel the talents and creativity of all 
family members in accordance with religious norms and values, (4) Hold discussion contacts for all family members by discussing or discussing matters related to the problems faced family. In addition, the need for curative measures as an effort to cure social order include (1) Reduce the factors that cause divorce, for example; fulfill his physical and spiritual needs, (2) Inculcate religious understanding to husband and wife how important it is to maintain the unity of the household, by exercising the rights and obligations as husband and wife, (3) inculcating discipline, for example; live orderly, orderly including in terms of discipline and customs courtesy. There is a need for legal action in the event of a violent divorce until it leads to a change of order to social decadence, which has been directed, warned and reprimanded before, but it is deemed necessary to be punished according to his actions.

\section{References}

Abdurrahaman, Human, AA. 2003. Merajut Kehidupan Pasca Pernikahan. Panduan Menuju Rumah Tangga Islami. Editor: Moekhotim El-Moekry. Jakarta: Kyber Graphics.

Beilharz, Peter. 2003. Teori-Teori Sosial. Obervasi Kritis Terhadap Para Filosof Terkemuka. Yogyakarat: Pustaka Pelajar.

Gemari. 2007. Kekerasan Dalam Rumah Tangga Meningkat. Dalam Majalah Keluarga Mandiri, Edisi 77/Tahun VIII-Juni. Jakarta: Yayasan Dana Sejahtera Mandiri.

Gulardi, Sri Tresnaningtias. 1999. Perubahan Nilai Di Kalangan Wanita yang Bercerai. Bunga Rampai Sosiologi Keluarga. Penyunting: T.O. Ihromi. Jakarta: Yayasan Obor Indonesia.

Ihromi, T.O. 1999. Berbagai Kerangka Konseptual dalam Pengkajian Keluarga. Bunga Rampai Sosiologi Keluarga. Penyunting: T.O. Ihromi. Jakarta: yayasan Obor Indonesia.

Karim, Erna, 1999. Pendekatan Perceraian dari Perspektif Sosiologi. Bunga Rampai Sosiologi Keluarga. Penyunting: T.O. Ihromi. Jakarta: Yayasan Obor Indonesia.

Kahmad, Dadang, 2000, Metode Penelitian Agama, Bandung: CV Pustaka Setia.

Nawawi, Hadari. 2007. Metode Penelitian Bidang Sosial. Jakarta: Gajah Mada University Press.

Sanafiah, Faisal. 1995. Penelitian Kualitatif: Dasar-Dasar dan Aplikasi. Jakarta: Rajawali Press.

Shiddiq, H. Humay M. Djafar. 2004. Indahnya Keluarga Sakinah. Dalam Al-Qur'an dan Sunnah. Jakarta: Zakia Press.

Soekanto, Soerjono. 1993. Sosiologi Suatu Pengantar. Jakarta : PT. Raja Grafindo Persada.

Sztompka, Piotr. 2004. Sosiologi Perubahan Sosial. Jakarta : Prenada.

The Liang Gie. 1993. Keadilan Sebagai Landasan Bagi Etika Administrasi Pemerintahan Dalam Negara Indonesia. Yogyakarta: Liberty.

Yusuf, Husein Muhammad.1995. Keluarga Muslim dan Tantangannya. Jakarta : Gema Insani Press. 